\title{
ANALISIS PELAKSANAAN PRAKTIKUM MATA KULIAH BIOLOGI UMUM PROGRAM STUDI PENDIDIKAN MATEMATIKA IKIP PGRI PONTIANAK
}

\author{
Ivan Eldes Dafrita ${ }^{1}$, Dwi Oktaviana ${ }^{2}$ \\ 1,2Prodi Pendidikan Matematika, Fakultas Pendidikan MIPATEK, IKIP PGRI Pontianak \\ ivaneldes83@gmail.com
}

\begin{abstract}
The purpose of this study is to analyze whether there is a significant correlation between the practicum to final grade of the General Biology subject of Mathematics Education student IKIP PGRI Pontianak. Research subjects are all students of Mathematics Education which follow the subjects and practicum of General Biology starting from academic year 2014/2015 until 2016/2017. Instrument in this research is documentation of data result of practicum and final score of General Biology of academic year 2014/2015 until 2016/2017. Based on the result of research and discussion, it can be concluded that there is a significant correlation between the practicum to final score of the General Biology subject of Mathematics Education Student IKIP PGRI Pontianak for the academic year 2014/2015, 2015/2016, and 2016/2017 with the result of $p$ value (Asymp Sig 2 tailed) of 0.000 is smaller than 0.05
\end{abstract}

Keywords: correlation, practicum, final score.

\section{PENDAHULUAN}

Tujuan Pendidikan Nasional yang tercantum dalam Undang-Undang No. 20 Tahun 2003 adalah mengembangkan potensi peserta didik agar menjadi manusia yang beriman dan bertakwa kepada Tuhan Yang Maha Esa, berakhlak mulia, sehat, berilmu, cakap, kreatif, mandiri, dan menjadi warga negara yang demokratis serta bertanggung jawab. Lebih lanjut dinyatakan dalam Peraturan Pemerintah Republik Indonesia No. 19 Tahun 2005 tentang Standar Nasional Pendidikan (SNP), bahwa standar kompetensi lulusan adalah kualifikasi kemampuan lulusan yang mencakup sikap, pengetahuan dan keterampilan.

Salah satu mata kuliah yang diajarkan di Program Studi Pendidikan Matematika IKIP PGRI Pontianak adalah Biologi Umum. Biologi merupakan bagian dari Ilmu Pengetahuan Alam (IPA) yang harus disampaikan sesuai dengan hakikat sains, yaitu sains sebagai produk, sains sebagai proses, dan sains sebagai sikap. Biologi sebagai produk meliputi sekumpulan pengetahuan yang terdiri atas fakta-fakta, konsep-konsep, dan prinsip-prinsip Biologi. 
Ivan Eldes Dafrita ${ }^{1}$, Dwi Oktaviana ${ }^{2}$ : Analisis Pelaksanaan Praktikum Mata Kuliah Biologi Umum Program Studi Pendidikan Matematika IKIP PGRI Pontianak

Biologi sebagai proses meliputi dengan pembelajaran yang berorientasi pada keterampilan-keterampilan yang dimunculkan selama proses pembelajaran. Keterampilan tersebut juga dikenal dengan keterampilan proses sains, yang meliputi: (1) observasi; (2) klasifikasi; (3) interpretasi; (4) prediksi; (5) hipotesis; (6) mengendalikan variabel; (7) merencanakan dan melaksanakan penelitian; (8) inferensi; (9) aplikasi; dan (10) komunikasi. Biologi sebagai sikap meliputi sikap-sikap ilmiah yang diharapkan muncul setelah proses pembelajaran, meliputi: (1) sikap ingin tahu; (2) sikap ingin mendapatkan sesuatu yang baru; (3) sikap kerja sama; (4) sikap tidak putus asa; (5) sikap tidak berprasangka; (6) sikap mawas diri; (7) sikap bertanggung jawab; (8) sikap berpikir bebas; (9) sikap kedisiplinan diri.

Pada kenyataannya, belum semua mata kuliah di Program Studi Pendidikan Matematika IKIP PGRI Pontianak disampaikan dengan memperhatikan hakikat sains. Pembelajaran pada umumnya masih bersifat konvensional dengan dosen berperan sebagai pusat pembelajaran (teacher centered). Hal ini meyebabkan rendahnya partisipasi serta pemahaman konsep mahasiswa dalam pembelajaran. Oleh karena itu, diperlukan adanya suatu mekanisme khusus bagi mahasiswa agar dapat menerima informasi dengan jelas dan menyimpannya dalam memori, misalnya mahasiswa (student centered).

Pembelajaran yang berorientasi pada mahasiswa, salah satunya dapat dilakukan melalui praktikum. Praktikum dilaksanakan dalam upaya memberikan kesempatan pada mahasiswa untuk mengaitkan konsep yang didapatkan selama perkuliahan dengan kehidupan mahasiswa secara nyata. Mempelajari dan memahami Biologi tidak cukup dengan penyampaian teori saja, akan tetapi perlu adanya pembelajaran bersifat eksperimental yang memberikan pengalaman belajar pada mahasiswa. Melalui praktikum, mahasiswa ikut berperan aktif dan melakukan suatu proses kerja ilmiah dalam menemukan ataupun membuktikan suatu konsep. Bagi mahasiswa yang memiliki rasa ingin tahu tinggi, melalui praktikum mereka dapat memperoleh jawaban dari rasa ingin tahunya secara nyata.

Eksperimen dalam praktikum Biologi membantu mahasiswa mendapatkan keterampilan-keterampilan teknis, misalnya memanipulasi peralatan dan material, observasi, pengumpulan data, analisis data, interpretasi hasil observasi, pemecahan masalah, kerja tim, dan keterampilan berkomunikasi (Limniou et al., 2008). Lebih lanjut, Witteck et al. (2007) menyatakan bahwa praktikum merupakan komponen esensial untuk mengajarkan metode ilmiah dan memahami hakekat sains. 
Hal senada dinyatakan oleh Hodson (dalam Pullailla, et al., 2007), bahwa kegiatan laboratorium dalam pembelajaran sains bertujuan untuk membangkitkan minat mahasiswa, mengajarkan keterampilanketerampilan laboratorium, membantu memperoleh dan mengembangkan konsep, menanamkan sikap ilmiah, dan mengembangkan keterampilan sosial.

Praktikum di laboratorium menyediakan lingkungan belajar yang unik dan memberikan kesempatan kepada mahasiswa untuk terlibat aktif dalam proses penyelidikan dan inkuiri. Hasil penyelidikan dan inkuiri ini diharapkan dapat memberikan makna belajar yang lebih bagi mahasiswa (Hofstein dan Lunneta, dalam Domin, 2007). Dapat disimpulkan dari berbagai pendapat diatas bahwa praktikum di laboratorium akan memberikan kesempatan pada mahasiswa untuk aktif menemukan dan membuktikan konsep melalui proses inkuiri, mengajarkan keterampilan-keterampilan proses sains, serta membuat pembelajaran menjadi lebih bermakna.

\section{Menurut Willington (dalam}

Ketpichainarong \& Ruenwongsa, 2010), manfaat praktikum bagi mahasiswa dapat diringkas menjadi tiga domain, yaitu untuk mengembangkan: (1) domain kognitif, misalnya konten sains dan hakekat sains; (2) domain psikomotorik, misalnya keterampilan proses sains, keterampilan laboratorium, keterampilan pemecahan masalah, serta keterampilan berpikir; dan (3) domain afektif, miaslnya menumbuhkan sikap positif terhadap sains.

Mata kuliah Biologi Umum di Program Studi Pendidikan Matematika IKIP PGRI Pontianak terintegrasi antara teori dan praktikum. Penyampaian teori dilakukan pada saat perkuliahan, sedangkan praktikum dilakukan dengan tujuan untuk memberikan kesempatan pada mahasiswa untuk memahami konsep yang telah didapatkan dalam perkuliahan secara lebih mendalam, menemukan konsep baru dan membuktikan kebenaran konsep dengan mengaplikasikannya secara terkontrol dalam lingkungan laboratorium, menumbuhkan sikap ilmiah serta mengkaitkan antara konsep yang didapatkan dengan apa yang ditemukan di kehidupan sehari-hari. Integrasi antara teori dan praktikum ini sesuai dengan pembelajaran Biologi Umum yang seharusnya, yaitu mengacu pada hakekat sains: sains sebagai produk, sains sebagai proses, dan sains sebagai sikap. Berdasarkan dari latar belakang, peneliti mencoba menganalisis apakah terdapat korelasi signifikan antara praktikum terhadap nilai akhir mata kuliah Biologi Umum mahasiswa Program Studi Pendidikan Matematika IKIP PGRI Pontianak. 
Ivan Eldes Dafrita ${ }^{1}$, Dwi Oktaviana ${ }^{2}$ : Analisis Pelaksanaan Praktikum Mata Kuliah Biologi Umum Program Studi Pendidikan Matematika IKIP PGRI Pontianak

\section{METODE PENELITIAN}

Penelitian termasuk penelitian deskriptif yang bertujuan untuk melakukan analisis pelaksanaan praktikum Biologi Umum mahasiswa Program Studi Pendidikan Matematika IKIP PGRI Pontianak. Rancangan dalam penelitian ini menggunakan korelasi antara nilai praktikum dengan nilai akhir mata kuliah Biologi Umum. Penelitian akan dilaksanakan di IKIP-PGRI Pontianak. Populasi dalam penelitian ini adalah seluruh mahasiswa Program Studi Pendidikan Matematika yang mengikuti mata kuliah dan praktikum Biologi Umum mulai dari tahun akademik 2014/2015 sampai 2016/2017. Sampel yang digunakan adalah sampel jenuh dimana setiap anggota populasi digunakan sebagai sampel.

Teknik pengumpul data dalam penelitian teknik dokumentasi dengan alat pengumpul datanya berupa dokumentasi data-data hasil praktikum dan nilai akhir mata kuliah Biologi Umum tahun akademik 2014/2015 sampai 2016/2017. Pada penelitian mengenai hasil praktikum dan nilai akhir mata kuliah Biologi Umum, dianalisis dengan statistik deskriptif. Data yang diperoleh dihitung nilai rata-rata dan standar deviasinya. Sedangkan untuk mengetahui ada tidaknya korelasi signifikan antara praktikum terhadap nilai akhir mata kuliah Biologi Umum mahasiswa Program Studi Pendidikan Matematika IKIP PGRI
Pontianak, maka data dianalisis menggunakan uji $\mathrm{t}$ untuk populasi tidak independen (populasi berpasangan) jika uji normalitas berdistribusi normal (Budiyono, 2013). Sedangkan jika uji normalitas berdistribusi tidak normal maka dilakukan uji Wilcoxon (Sugiyono, 2013).

\section{HASIL DAN PEMBAHASAN}

Data dalam penelitian ini meliputi data hasil praktikum dan nilai akhir pada mata kuliah Biologi umum dari tahun akademik 2014/2015, 2015/2016, dan 2016/2017. Adapun data tersebut sebagai berikut:

a. Data Hasil Praktikum dan Nilai Akhir Tahun Akademik 2014/2015

Analisis deskriptif pada hasil praktikum dan nilai akhir digunakan untuk mengetahui nilai rata-rata, dan standar deviasi pada kedua variabel tersebut. Hasilnya dapat dilihat secara jelas pada Tabel 1: 
Buana Matematika: Jurnal Ilmiah Matematika dan Pendidikan Matematika Volume 8, Nomor 1, Tahun 2018

Tabel 1. Deskripsi Kedua Variabel Data Tahun Akademik 2014/2015

Descriptive Statistics

\begin{tabular}{lcrrrr}
\hline & N & Minimum & Maximum & Mean & Std. Deviation \\
\hline Hasil Praktikum & 139 & 52 & 89 & 66.52 & 7.694 \\
Nilai Akhir & 139 & 50 & 88 & 70.65 & 7.905 \\
Valid N (listwise) & 139 & & & & \\
\hline
\end{tabular}

Berdasarkan Tabel 1 hasil analisis dan standar deviasi 7,694, sedangkan ratadeskripsi kedua variabel diketahui bahwa rata untuk nilai akhir adalah 70,65 dan rata-rata untuk hasil praktikum adalah 66,52 standar deviasi 7,905.

b. Data Hasil Praktikum dan Nilai Akhir Tahun Akademik 2015/2016

Analisis deskriptif pada hasil praktikum dan nilai akhir digunakan untuk mengetahui nilai rata-rata, dan standar deviasi pada kedua variabel tersebut. Hasilnya dapat dilihat secara jelas pada Tabel 2:

Tabel 2. Deskripsi Kedua Variabel Data Tahun Akademik 2015/2016

\section{Descriptive Statistics}

\begin{tabular}{|c|c|c|c|c|c|}
\hline & $\mathrm{N}$ & Minimum & Maximum & Mean & Std. Deviation \\
\hline Hasil Praktikum & 80 & 10 & 81 & 59.89 & 8.705 \\
\hline Nilai Akhir & 80 & 14 & 84 & 65.24 & 11.124 \\
\hline Valid N (listwise) & 80 & & & & \\
\hline
\end{tabular}

Berdasarkan Tabel 2 hasil analisis Analisis deskriptif pada hasil praktikum deskripsi kedua variabel diketahui bahwa dan nilai akhir digunakan untuk rata-rata untuk hasil praktikum adalah mengetahui nilai rata-rata, dan standar 59,89 dan standar deviasi 8,705, sedangkan deviasi pada kedua variabel tersebut. rata-rata untuk nilai akhir adalah 65,24 dan Hasilnya dapat dilihat secara jelas pada standar deviasi 11,124. Tabel 3:

c. Data Hasil Praktikum dan Nilai Akhir

Tahun Akademik 2016/2017 
Ivan Eldes Dafrita ${ }^{1}$, Dwi Oktaviana ${ }^{2}$ : Analisis Pelaksanaan Praktikum Mata Kuliah Biologi Umum Program Studi Pendidikan Matematika IKIP PGRI Pontianak

Tabel 3. Deskripsi Kedua Variabel Data Tahun Akademik 2016/2017

\begin{tabular}{lcrrrr}
\hline \multicolumn{7}{c}{ Descriptive Statistics } \\
\hline Hasil Praktikum & 112 & 43 & 84 & 61.64 & 6.830 \\
Nilai Akhir & 112 & 50 & 85 & 67.47 & 7.649 \\
Valid N (listwise) & 112 & & & & Minimum \\
\hline
\end{tabular}

Berdasarkan Tabel 3 hasil analisis yang dihitung dengan menggunakan bantuan deskripsi kedua varariabel diketahui bahwa program SPSS 16.0 for windows.

rata-rata untuk hasil praktikum adalah 61,64 a. Uji Normalitas dan standar deviasi 6,830, sedangkan ratarata untuk nilai akhir adalah 67,47 dan standar deviasi 7,649.

Selanjutnya sebelum melakukan pengolahan data berkaitan dengan terdapat korelasi antara praktikum dan nilai akhir dengan menggunakan uji t untuk populasi tidak independen (populasi berpasangan) terlebih dahulu dilakukan uji prasyarat. Uji prasyarat tersebut meliputi uji normalitas

Pengujian normalitas digunakan untuk mengetahui data hasil praktikum dan nilai akhir yang diselidikui dalam populasi berdistribusi normal atau tidak.

1) Hasil Praktikum dan Nilai Akhir Tahun Akademik 2014/2015

Berdasarkan hasil uji normalitas dengan Kolmogorov-Smirnov, kedua variabel memberikan hasil yang dapat dilihat pada Tabel 4.

Tabel 4. Hasil Uji Normalitas Kedua Variabel Tahun Akademik 2014/2015

\section{Tests of Normality}

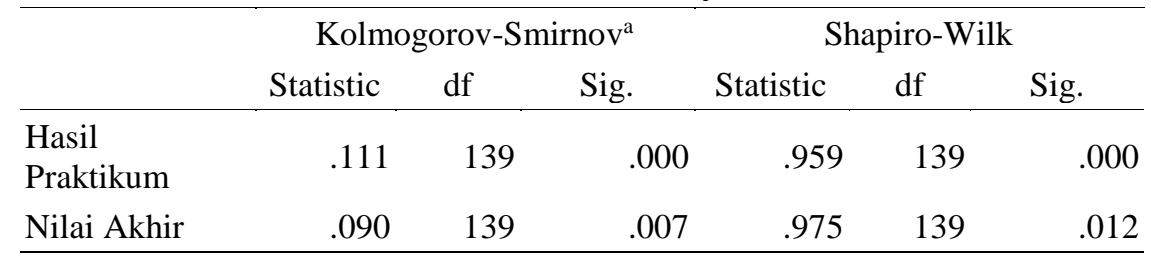

a. Lilliefors Significance Correction

Berdasarkan Tabel 4 dikatakan bahwa nilai signifikan untuk variabel hasil praktikum mahasiswa dalam mata kuliah biologi umum sebesar 0.000, nilai signifikansi untuk variabel hasil praktikum mahasiswa dalam mata kuliah biologi umum lebih kecil dari 0,05 maka dapat disimpulkan bahwa hasil praktikum mahasiswa dalam mata kuliah biologi umum tidak berdistribusi normal. Nilai signifikansi untuk variabel nilai akhir sebesar 0.007 , nilai signifikansi untuk variabel nilai akhir lebih 
Buana Matematika: Jurnal Ilmiah Matematika dan Pendidikan Matematika Volume 8, Nomor 1, Tahun 2018

p-ISSN 2088-3021

$e$-ISSN 2598-8077

kecil dari 0,05 maka dapat disimpulkan bahwa data nilai akhir juga tidak berdistribusi normal.

2) Hasil Praktikum dan Nilai Akhir Tahun Akademik 2015/2016
Berdasarkan hasil uji normalitas dengan Kolmogorov-Smirnov, kedua variabel memberikan hasil yang dapat dilihat pada Tabel 5.

Tabel 5. Hasil Uji Normalitas Kedua Variabel Tahun Akademik 2015/2016

Tests of Normality

\begin{tabular}{lrrrrrr}
\hline & \multicolumn{3}{c}{ Kolmogorov-Smirnov $^{\mathrm{a}}$} & \multicolumn{3}{c}{ Shapiro-Wilk } \\
& Statistic & \multicolumn{1}{c}{ df } & \multicolumn{1}{c}{ Sig. } & Statistic & \multicolumn{1}{c}{ df } & \multicolumn{1}{c}{ Sig. } \\
\hline Hasil Praktikum & .187 & 80 & .000 & .754 & 80 & .000 \\
Nilai Akhir & .194 & 80 & .000 & .809 & 80 & .000 \\
\hline
\end{tabular}

a. Lilliefors Significance Correction

Berdasarkan Tabel 5 dikatakan bahwa nilai signifikan untuk variabel hasil praktikum mahasiswa dalam mata kuliah biologi umum sebesar 0.000, nilai signifikansi untuk variabel nilai praktikum mahasiswa dalam mata kuliah biologi umum lebih kecil dari 0,05 maka dapat disimpulkan bahwa hasil praktikum mahasiswa dalam mata kuliah biologi umum tidak berdistribusi normal. Nilai signifikansi untuk variabel nilai akhir sebesar 0.000 , nilai signifikansi untuk variabel nilai akhir lebih kecil dari 0,05 maka dapat disimpulkan bahwa data nilai akhir juga tidak berdistribusi normal.

3) Hasil Praktikum dan Nilai Akhir Tahun Akademik 2016/2017

Berdasarkan hasil uji normalitas dengan

Kolmogorov-Smirnov, kedua variabel memberikan hasil yang dapat dilihat pada Tabel 6.

Tabel 6. Hasil Uji Normalitas Kedua Variabel Tahun Akademik 2016/2017

\section{Tests of Normality}

\begin{tabular}{lcccccc}
\hline & \multicolumn{3}{c}{ Kolmogorov-Smirnov $^{\mathrm{a}}$} & \multicolumn{3}{c}{ Shapiro-Wilk } \\
& Statistic & df & \multicolumn{1}{c}{ Sig. } & Statistic & \multicolumn{1}{c}{ df } & \multicolumn{1}{c}{ Sig. } \\
\hline Hasil Praktikum & .101 & 112 & .007 & .982 & 112 & .135 \\
Nilai Akhir & .147 & 112 & .000 & .981 & 112 & .118 \\
\hline
\end{tabular}

a. Lilliefors Significance Correction

Berdasarkan Tabel 6 dikatakan bahwa praktikum mahasiswa dalam mata kuliah nilai signifikan untuk variabel hasil biologi umum sebesar 0.007 , nilai 
Ivan Eldes Dafrita ${ }^{1}$, Dwi Oktaviana ${ }^{2}$ : Analisis Pelaksanaan Praktikum Mata Kuliah Biologi Umum Program Studi Pendidikan Matematika IKIP PGRI Pontianak

signifikansi untuk variabel hasil praktikum mahasiswa dalam mata kuliah biologi umum lebih kecil dari 0,05 maka dapat disimpulkan bahwa hasil praktikum mahasiswa dalam mata kuliah biologi umum tidak berdistribusi normal. Nilai signifikansi untuk variabel nilai akhir sebesar 0.000 , nilai signifikansi untuk variabel nilai akhir lebih kecil dari 0,05 maka dapat disimpulkan bahwa data nilai akhir juga tidak berdistribusi normal.

b. Uji Hipotesis
Karena data penelitian dari tahun akademik 2014/2015, 2015/2016, dan 2016/2017 tidak berdistribusi normal maka untuk menguji hipitesis yaitu apakah terdapat korelasi signifikan antara praktikum dan nilai akhir pada mata kuliah Biologi Umum digunakan uji Wilcoxon.

1) Hasil Praktikum dan Nilai Akhir Tahun Akademik 2014/2015

Hasil analisis uji Wilcoxon antara praktikum dan nilai akhir dapat dilihat pada Tabel 7.

Tabel 7. Uji Wilcoxon Data Penelitian Tahun Akademik 2014/2015

\section{Test Statistics ${ }^{b}$}

\begin{tabular}{lr}
\hline & $\begin{array}{c}\text { Nilai Akhir - Nilai } \\
\text { Praktikum }\end{array}$ \\
\hline$Z$ & $-6.376^{\mathrm{a}}$ \\
Asymp. Sig. (2-tailed) & .000 \\
\hline
\end{tabular}

a. Based on negative ranks.

b. Wilcoxon Signed Ranks Test

diterima berarti terdapat korelasi signifikan

Berdasarkan Tabel 7 nampak bahwa nilai $Z$ yang didapat sebesar -6,376 dengan $p$ value (Asymp. Sig 2 tailed) sebesar 0.000 . Guna menerima atau menolak hipotesis, didasarkan pada kriteria pengujian. Jika nilai p value (Asymp. Sig 2 tailed) $<0,05$ maka $\mathrm{H}_{0}$ ditolak $\left(\mathrm{H}_{\mathrm{a}}\right.$ diterima) dan sebaliknya. Karena nilai $\mathrm{p}$ value (Asymp. Sig 2 tailed) sebesar 0.000 lebih kecil dari 0,05 maka $\mathrm{H}_{\mathrm{a}}$ antara praktikum terhadap nilai akhir mata kuliah Biologi Umum mahasiswa Program Studi Pendidikan Matematika IKIP PGRI Pontianak.

2) Hasil Praktikum dan Nilai Akhir Tahun Akademik 2015/2016

Hasil analisis uji Wilcoxon antara praktikum dan nilai akhir dapat dilihat pada Tabel 8. 
Buana Matematika: Jurnal Ilmiah Matematika dan Pendidikan Matematika Volume 8, Nomor 1, Tahun 2018

Tabel 8. Uji Wilcoxon Data Penelitian Tahun Akademik 2015/2016

Test Statistics ${ }^{b}$

\begin{tabular}{lr}
\hline & \multicolumn{2}{c}{ Nilai Akhir - } \\
& Nilai Praktikum \\
\hline $\mathrm{Z}$ & $-5.366^{\mathrm{a}}$ \\
Asymp. Sig. (2-tailed) & .000 \\
\hline
\end{tabular}

a. Based on negative ranks.

b. Wilcoxon Signed Ranks Test

Berdasarkan Tabel 8 nampak bahwa antara praktikum terhadap nilai akhir mata nilai $\mathrm{Z}$ yang didapat sebesar -5,366 dengan $\mathrm{p}$ kuliah Biologi Umum mahasiswa Program value (Asymp. Sig 2 tailed) sebesar 0.000. Studi Pendidikan Matematika IKIP PGRI Guna menerima atau menolak hipotesis, didasarkan pada kriteria pengujian. Jika nilai Pontianak.

p value (Asymp. Sig 2 tailed) $<0,05$ maka

3) Hasil Praktikum dan Nilai Akhir Tahun $\mathrm{H}_{0}$ ditolak ( $\mathrm{H}_{\mathrm{a}}$ diterima) dan sebaliknya. Akademik 2016/2017

Hasil analisis uji Wilcoxon antara Karena nilai $\mathrm{p}$ value (Asymp. Sig 2 tailed) sebesar 0.000 lebih kecil dari $0,05{\text { maka } \mathrm{H}_{\mathrm{a}}}$ praktikum dan nilai akhir dapat dilihat pada Tabel 9.

diterima berarti terdapat korelasi signifikan

Tabel 9. Uji Wilcoxon Data Penelitian Tahun Akademik 2016/2017

\begin{tabular}{|c|c|}
\hline \multicolumn{2}{|c|}{ Test Statistics $^{\text {b }}$} \\
\hline & $\begin{array}{c}\text { Nilai Akhir - } \\
\text { Nilai Praktikum }\end{array}$ \\
\hline $\mathrm{Z}$ & $-7.320^{\mathrm{a}}$ \\
\hline Asymp. Sig. (2-tailed) & .000 \\
\hline
\end{tabular}

Berdasarkan Tabel 9 nampak bahwa nilai $Z$ yang didapat sebesar -7,320 dengan $p$ value (Asymp. Sig 2 tailed) sebesar 0.000 . Guna menerima atau menolak hipotesis, didasarkan pada kriteria pengujian. Jika nilai p value (Asymp. Sig 2 tailed) $<0,05$ maka $\mathrm{H}_{0}$ ditolak $\left(\mathrm{H}_{\mathrm{a}}\right.$ diterima $)$ dan sebaliknya. Karena nilai $\mathrm{p}$ value (Asymp. Sig 2 tailed) sebesar 0.000 lebih kecil dari 0,05 maka $\mathrm{H}_{\mathrm{a}}$ diterima berarti terdapat korelasi signifikan antara praktikum terhadap nilai akhir mata kuliah Biologi Umum mahasiswa Program Studi Pendidikan Matematika IKIP PGRI Pontianak.

Penelitian yang dilakukan adalah penelitian deskriptif dengan tujuan setelah 
Ivan Eldes Dafrita ${ }^{1}$, Dwi Oktaviana ${ }^{2}$ : Analisis Pelaksanaan Praktikum Mata Kuliah Biologi Umum Program Studi Pendidikan Matematika IKIP PGRI Pontianak

dilakukan praktikum adalah ingin dengan effect size sebesar 0,74 dan termasuk mengetahui apakah terdapat korelasi signifikan antara praktikum terhadap nilai akhir. Penelitian ini dilaksanakan di IKIP PGRI Pontianak pada mahasiswa Pendidikan Matematika tahun akademik 2014/2015, 2015/2016, dan 2016/2017 pada mata kuliah Biologi Umum. Ada beberapa penelitian yang menggunakan metode praktikum untuk meningkatkan hasil belajar siswa antara lain penelitian yang dilakukan oleh Farid dan Pramukantoro, (2006) dan Hastuti, (2013) menyatakan bahwa pembelajaran metode praktikum ini dapat meningkatkan hasil belajar.

Setelah dilakukan pembelajaran praktikum ini kembali dilakukan ujian akhir semester untuk mendapatkan nilai akhir mahasiswa pada mata kuliah Biologi Umum. Berdasarkan data hasil penelitian menunjukkan bahwa terdapat korelasi signifikan antara praktikum terhadap nilai akhir mata kuliah Biologi Umum mahasiswa Program Studi Pendidikan Matematika IKIP PGRI Pontianak baik untuk data tahun akademik 2014/2015, 2015/2016, dan 2016/2017 dengan nilai p value (Asymp. Sig 2 tailed) sebesar 0.000 lebih kecil dari 0,05 pada ketiga data tahun akademik. Hal ini sesuai dengan penelitian yang dilakukan oleh Hastuti, (2013) pengaruh pembelajaran metode praktikum dapat meningkatkan hasil belajar kognitif siswa sebesar 6,67 poin kategori efek sedang.

Pembelajaran dengan memberikan praktikum lebih melibatkan mahasiswa dalam proses pembelajaran sehingga mahasiswa lebih aktif dan bersemangat. Dengan pembelajaran yang menggunakan praktikum, mahasiswa diberi kondisi belajar yang dapat mengembangkan kemampuan berpikir dan kreativitas secara optimal. Hal itu terjadi karena mahasiswa diberi kesempatan untuk melakukan percobaan tentang sesuatu hal, mengamati prosesnya dan menuliskan hasil percobaannya, kemudian hasil pengamatan itu disampaikan di kelas dan dievaluasi oleh dosen. Kesempatan untuk melakukan percobaan membuat mahasiswa memiliki kemampuan menyusun konsep dalam struktur kognitifnya, selanjutnya dapat diaplikasikan dalam kehidupan nyata. Selain itu, dengan diberikan praktikum mahasiswa dituntut untuk dapat mengembangkan pengetahuannya dengan cara mengalami langsung, mengamati langsung proses pembelajaran tersebut. Sehingga dengan demikian mahasiswa dapat membangun pengetahuannya sendiri serta pembelajaran yang dilakukan lebih bermakna.

Pernyataan Shoenher dalam (Yulaida, 2016), bahwa metode praktikum adalah metode yang sesuai untuk pembelajaran sains, karena metode praktikum mampu memberikan kondisi 
Buana Matematika: Jurnal Ilmiah Matematika dan Pendidikan Matematika Volume 8, Nomor 1, Tahun 2018

p-ISSN 2088-3021

$e$-ISSN 2598-8077

belajar yang mengembangkan kemampuan berpikir dan kreatifitas secara optimal. Terbukti pada kegiatan-kegiatan yang dilakukan oleh para mahasiswa dalam melakukan praktikum dan membuat para mahasiswa berpikir tentang kesimpulan yang telah mereka lakukan. Praktikum pada pelaksanaannya,

mahasiswa mempraktekkan sendiri materi yang dipelajari sehingga lebih mudah diingat dan dipahami oleh mahasiswa. Hal ini sesuai dengan pernyataan confusius dalam (Yulaida, 2016) yaitu "apa yang saya lihat, saya ingat, apa yang saya kerjakan, saya paham". Jadi pada dengan diadakannya praktikum mahasiswa tidak hanya sekedar mengingat materi saja, namun juga memahaminya.

\section{SIMPULAN DAN SARAN}

Berdasarkan hasil penelitian dan pembahasan maka dapat diperoleh kesimpulan sebagai berikut: (1) Hasil praktikum Biologi Umum mahasiswa Program Studi Pendidikan Matematika IKIP PGRI Pontianak pada tahun akademik 2014/2015 memperoleh rata-rata untuk hasil praktikum adalah 66,52 dan standar deviasi 7,694, sedangkan tahun akademik 2015/2016 memperoleh rata-rata untuk hasil praktikum adalah 59,89 dan standar deviasi 8,705, dan tahun akademik 2016/2017 memperoleh rata-rata untuk hasil praktikum adalah 61,64 dan standar deviasi 6,830; (2) Nilai akhir
Biologi Umum mahasiswa Program Studi Pendidikan Matematika IKIP PGRI Pontianak pada tahun akademik 2014/2015 memperoleh rata-rata untuk nilai akhir adalah 70,65 dan standar deviasi 7,905, sedangkan tahun akademik 2015/2016 memperoleh rata-rata untuk nilai akhir adalah 65,24 dan standar deviasi 11,124, dan tahun akademik 2016/2017 memperoleh rata-rata untuk nilai akhir adalah 67,47 dan standar deviasi 7,649; dan (3) Terdapat korelasi signifikan antara praktikum terhadap nilai akhir mata kuliah Biologi Umum mahasiswa Program Studi Pendidikan Matematika IKIP PGRI Pontianak baik untuk tahun akademik 2014/2015, 2015/2016, dan 2016/2017 dengan hasil nilai p value (Asymp. Sig 2 tailed) sebesar 0.000 lebih kecil dari 0,05.

\section{DAFTAR PUSTAKA}

Budiyono. (2013). Statistika Untuk Penelitian. Surakarta: UNS Press.

Domin, D. S. (2007). Student's Perceptions When Conceptual Development Occurs During Laboratory Instruction. Journal of Chemistry Education Research and Practice. 8(2), 140-152.

Farid, M., \& Pramukantoro, J.A. 2006. Model Pembelajaran Berbasis Praktikum dalam Meningkatkan 
Ivan Eldes Dafrita ${ }^{1}$, Dwi Oktaviana ${ }^{2}$ : Analisis Pelaksanaan Praktikum Mata Kuliah Biologi Umum Program Studi Pendidikan Matematika IKIP PGRI Pontianak

Hasil Belajar dan Motivasi Siswa. Journal unesa.ac.id.

Hastuti, Ani. (2013). Penerapan Pembelajaran Berbasis Praktikum Untuk Meningkatkan Motivasi dan Hasil Belajar Biologi Materi Pokok Sistem Reproduksi Manusia. Yogyakarta: UIN Sunan Kalijaga Yogyakarta.

Ketpichainarong, P. W., \& Ruenwongsa, W. (2010). Enhanced Learning of Biotechnology Students by An Inquiry-Based Cellulace Laboratory. International Journal of Environmental and Science Education. 5(2), 169-187.

Limniou, M., \& et al. (2008). The Integration of A Viscocity Simulator in A Chemistry Laboratory. Journal of Chemistry Education Research and Practice. 8(2), 220-231.

Peraturan Pemerintah Republik Indonesia No. 19 Tahun 2005: Standar Nasional Pendidikan.

Pullailla, A., Redjeki, S., \& Rusdiana, D.
Sugiyono. (2013). Metode Penelitian Pendidikan . Bandung: Alfabeta.

Undang-Undang No. 20 Tahun 2003: Tujuan Pendidikan Nasional.

Witteck, \& et al. (2007). A Lesson Plan on Methods of Separating Matter Based on the Learning Company Approach (A Motivating Frame for SelfRegulated and Open Lab Work in Introductory Secondary Chemistry Lessons). Journal of Chemistry Education Research and Practice. 8(2), 108-119.

Yulaida, Dewi. (2016). Pengaruh Metode Praktikum Terhadap Motivasi dan Hasil Belajar IPA Siswa Kelas IV SDN Kemiri I Puspo Pasuruan. Malang: UIN Maulana Malik Ibrahim Malang.

(2007). Model Pembelajaran Inkuiri

Terbimbing untuk Meningkatkan

Penguasaan Konsep dan

Keterampilan Berpikir Kreatif Siswa

SMA pada Materi Suhu dan Kalor.

Jurnal Pendidikan IPA. 1(3), 287-

295. 